A N N A L E S

UNIVERSITATIS MARIAE CURIE-SKŁODOWSKA LUBLIN - POLONIA

VOL. LXX, z. 2

SECTIO B

2015

Instytut Geografii i Gospodarki Przestrzennej, Uniwersytet Jagielloński

ul. Gronostajowa 7, 30-387 Kraków, p.franczak@uj.edu.pl

PAWEL FRANCZAK

\title{
Hydrologiczne i geomorfologiczne skutki ekstremalnego opadu w maju 2014 roku w zlewni Rybnego Potoku (Masyw Babiej Góry)
}

Hydrological and geomorphological effects of extreme precipitation in May 2014 in the Rybny Potok catchment (Babia Mountain Massif)

Słowa kluczowe: wezbranie, powódź błyskawiczna, przekształcenia geomorfologiczne, zlewnia Skawy, Karpaty thians

Key words: flash flood, geomorphological transformations, freshet, Skawa catchment, Carpa-

\section{WSTĘP}

Gwałtowne wezbrania są zjawiskami lokalnymi (Bryndal 2008), obejmującymi swym zasięgiem niewielkie obszary, przez co nie poświęcano im dotychczas w literaturze znaczącej uwagi. Za główne zagrożenie powodziowe powodujące duże straty materialne oraz znaczne przekształcenia geomorfologiczne w obrębie dolin uważane są wezbrania występujące w dnach większych rzek. Należy jednak zwrócić uwagę, że także lokalnie bardzo duże zagrożenie stwarzają również wezbrania występujące w małych zlewniach (Bryndal 2008, 2011; Pociask-Karteczka, Żychowski 2014), które zwłaszcza na obszarach górskich mogą przybierać katastrofalne rozmiary.

W małych zlewniach do wystąpienia gwałtownych wezbrań przyczyniają się krótkotrwałe (trwające do kilku godzin), bardzo intensywne opady deszczu (Parczewski 1960). Obejmują one swym zasięgiem niewielki obszar, który przeważnie nie przekracza $100 \mathrm{~km}^{2}$. Ponadto w $50 \%$ przypadków obszar intensywnych opadów nie przekracza $25 \mathrm{~km}^{2}$ (Lenart 1993; Bryndal 2010), przez co występuje na obszarze jednej bądź kilku przylegających do siebie małych zlewni. 
W rezultacie wystąpienia intensywnych opadów deszczu, następuje formowanie się w małych zlewniach gwałtownych fal wezbraniowych. Na obszarach zabudowanych wyrządzają one w wyniku wystąpienia powodzi znaczne straty materialne (Cabaj i in. 2002; Ziętara 2002; Bryndal 2011), które w przeliczeniu na $1 \mathrm{~km}^{2}$ powierzchni zlewni mogą dochodzić do 100 tys. zł (Bryndal 2014). Prócz strat materialnych gwałtowne wezbrania występujące w małych zlewniach górskich mogą przyczynić się do wystąpienia znacznych przekształceń geomorfologicznych, które pociągają za sobą zmiany w krajobrazie. Zmiany te jednak nie są takie same w całej zlewni. W części biegu potoku następuje intensywne pogłębianie koryta, natomiast na odcinkach o mniejszej energii wód wezbraniowych następuje akumulacja transportowanego materiału. Procesy te mogą jednak być modyfikowane w zależności od zlewni, w której występuje wezbranie. W zlewniach zalesionych proces ten jest silnie modyfikowany przez transportowaną materię organiczną (głównie gruby rumosz drzewny).

Gwałtowne wezbrania powodujące wystąpienie powodzi błyskawicznych były dotychczas przedmiotem zaledwie pojedynczych opracowań. Dostępne w literaturze wyniki badań z tego zakresu dotyczą przede wszystkim opisu przebiegu powodzi, wyrządzonych w ich wyniku strat materialnych, a także zaszłych przekształceń geomorfologicznych (Dębski 1969; Ciepielowski 1970; Żurawek 1999; Lach, Lewik 2002; Łach 2003; Gorczyca 2004; Bajgier-Kowalska, Ziętara 2008; Bryndal i in. 2008; Długosz, Gębica 2008; Gorczyca, Krzemień 2008; Gorczyca, Wrońska-Wałach 2008; Krzaklewski 2008; Izmaiłow i in. 2008; Bryndal 2009, 2011; Bucała Budek 2011; Starkel 2011).

Do wzrostu zainteresowania powodziami błyskawicznymi przyczyniły się badania prowadzone w ramach międzynarodowego programu HYDRATE (Hydrometeorological data resources and technologies for effective flash flood forecasting), w którym podjęto się analizy tych zjawisk w Europie (Gaume i in. 2009). Ponadto wzrost zainteresowania tą tematyką jest spowodowany wielkością strat, jakie powodują tego typu powodzie.

Celem opracowania była hydrometeorologiczna interpretacja wezbrania, które wystąpiło w dniu 31 lipca 2014 r. w zlewni Rybnego Potoku oraz analiza zmian geomorfologicznych zachodzących w małych zlewniach górskich w rezultacie gwałtownych wezbrań.

\section{OBSZAR BADAŃ}

Zlewnia Rybnego Potoku o powierzchni $9,19 \mathrm{~km}^{2}$ położona jest na północnych stokach Masywu Babiej Góry (Ryc. 1). Rybny Potok o długości 5,11 km jest lewobrzeżnym dopływem Jaworzyny, a ta Skawicy (Lajczak 2008). Zlewnia charakteryzuje się wydłużonym kształtem, z wyraźnie zaokrągloną źródłową częścią 


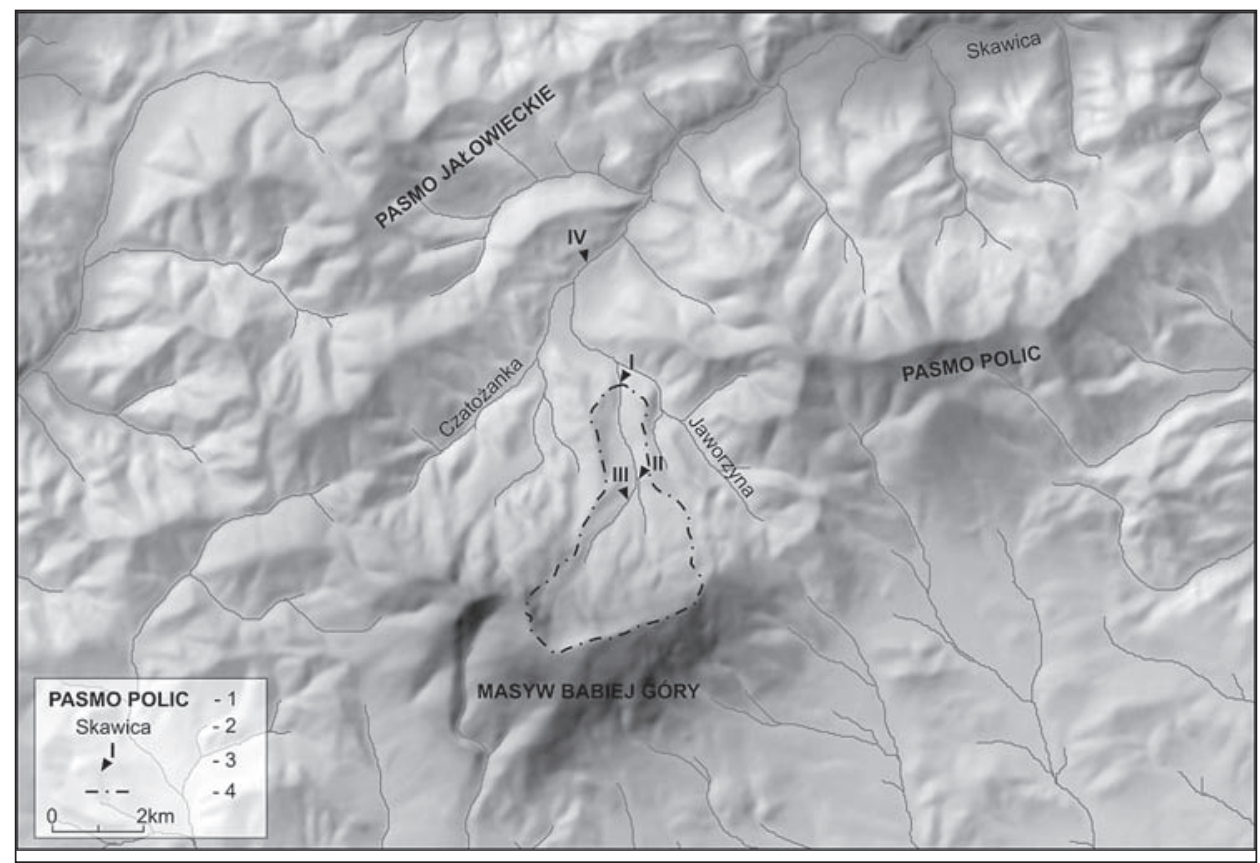

Ryc. 1. Lokalizacja obszaru badań: 1 - pasmo górskie, 2 - ciek, 3 - wodowskaz: I - Rybny Potok, II - Żarnowiecki Potok, III - Szumiąca Woda, 4 - Skawica w Zawoi, 4 - dział wodny Rybnego Potoku

Fig. 1. Location on the study area: 1 - range, 2 - river, 3 - stream gauge: I - Rybny Potok, II - Żarnowiecki Potok, III - Szumiąca Woda, 4 - Skawica w Zawoi, 4 - drainage divide of Rybny Potok

Źródło: opracowanie własne

Source: author's own study

zlewni, i wskaźnikiem kolistości wynoszącym 0,53. Gęstość sieci hydrograficznej w zlewni Rybnego Potoku sięga $1,73 \mathrm{~km} / \mathrm{km}^{2}$. Najwyższe partie zlewni, w linii działu wodnego, sięgają wysokości 1725 m n.p.m. (kulminacja masywu Babiej Góry - Diablak). Natomiast najniższy punkt (655 m n.p.m.) znajduje się w ujściu Rybnego Potoku do Jaworzyny. Zlewnia ta cechuje się zdecydowanie największą deniwelacją (1070 m) spośród wszystkich babiogórskich zlewni, oraz najwyższą średnią wysokością (1093 m n.p.m.) pośród zlewni położonych po północnej stronie masywu (Ryc. 2).

Zlewnia Rybnego Potoku jest zbudowana w większości przez gruboławicowe piaskowce magurskie oraz częściowo przez warstwy hieroglifowe (w dolnej części), charakteryzuje się wyraźną trójdzielnością rzeźby. Górne partie zlewni o nachyleniu często przekraczającym $40^{\circ}$ porozcinane są gęstą siecią żlebów. Poniżej nich rozciąga się szeroki pas wyścielony miąższami pokrywami koluwialnymi. Górne odcinki koryt występujące na tym obszarze wyróżniają się bardzo duży- 


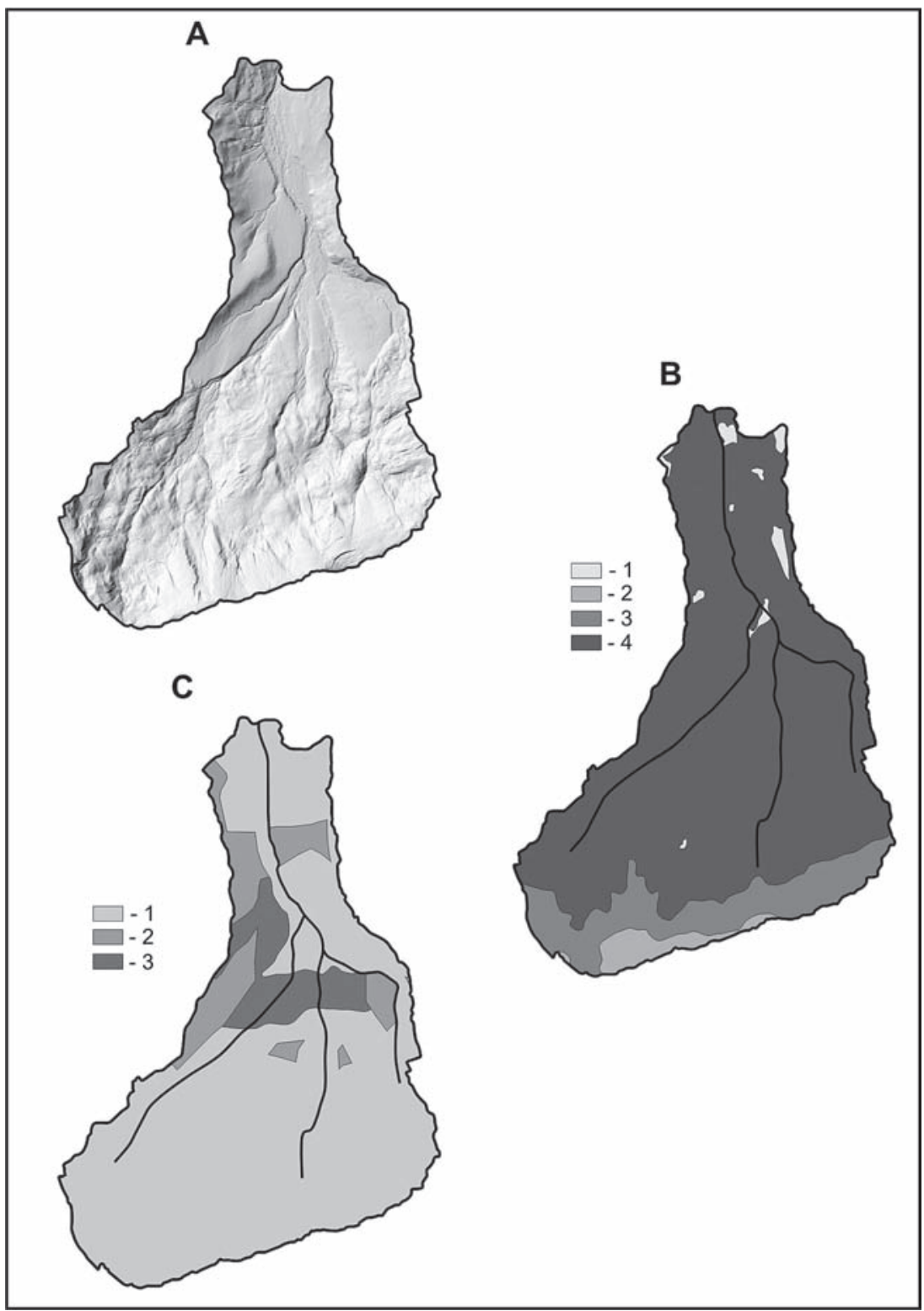

Ryc. 2. Teren badań; A - rzeźba terenu; B - użytkowanie: 1 - polana, 2 - piętro kosodrzewiny, 3 - piętro alpejskie, 4 - lasy; C - budowa geologiczna: 1 - piaskowce magurskie, 2 - warstwy hieroglifowe, 3 - żwiry, piaski, gliny teras $3-12 \mathrm{~m}$ nad poziomem dna doliny

Fig. 2. The study area: A - relief; B - structure of land use: 1 - glade, 2 - dwaef pine zone, 3 - alpine zone 4 - forest; $\mathrm{C}$ - geological map: 1 - magurskie sandstones, 2 - hieroglyphics, 3 - gravels, sands, clays terrace 3-12 m above the valley

Źródło: opracowanie własne

Source: author's own study 
mi spadkami (dochodzącymi do 350\%), natomiast spadek koryta w dolnym jego biegu jest znacznie mniejszy i wynosi ok. $80 \%$. W tej części dolina jest znacznie szersza niż ma to miejsce w gęsto rozczłonkowanych górnych partiach stoku. Szerokość koryta wynosi od 2-4 m w górnym odcinku potoku do 3-10 w dolnym. Większość zlewni porasta las (83\%), w górnej występuje kosodrzewina i murawy alpejskie (17\%) (Ryc. 2).

\section{MATERIAŁY I METODY BADAŃ}

Badania terenowe w zlewni Rybnego Potoku przeprowadzono w dwóch etapach. W dniach 16-19 maja 2014 r., przeprowadzono pomiary parametrów fali wezbraniowej oraz wydajności źródeł, a także wykonano dokumentację fotograficzną. W drugim etapie badań przeprowadzonym w dniach 22-25 maja 2014 r. wykonano kartowanie geomorfologiczne koryta Rybnego Potoku. Badania przeprowadzono z zastosowaniem metody kartowania terenowego opartego na raptularzu i instrukcji przygotowanej w Zakładzie Geomorfologii Instytutu Geografii i Gospodarki Przestrzennej Uniwersytetu Jagiellońskiego (Krzemień 2012). Na podstawie przeprowadzonego kartowania scharakteryzowano powstałe formy geomorfologiczne, a następnie podzielono koryto na odcinki erozyjne, akumulacyjne oraz transportowe. Określono także ich cechy ilościowe i jakościowe.

Wysokości opadów atmosferycznych, które spowodowały wezbranie oraz parametry fali wezbraniowej pozyskano w ramach prowadzonego od $2011 \mathrm{r}$. na obszarze Babiogórskiego Parku Narodowego monitoringu meteorologicznego i hydrologicznego. Wyniki te uzupełniono o dane pozyskane z IMGW-PIB. Dane meteorologiczne gromadzone $\mathrm{w}$ ramach sieci monitoringu IMGW-PIB pozyskano ze stacji meteorologicznych umiejscowionych w Zawoi (697 m n.p.m.) i Jabłonce (620 m n.p.m.). Monitoring opadów atmosferycznych na obszarze BgPN prowadzono na Rybnej Polanie (710 m n.p.m.) i Hali Śmietanowej (830 m n.p.m.) z wykorzystaniem deszczomierzy typu SEBA RG 50, firmy SEBA Hydrometrie $\mathrm{GmbH}$. Monitoring hydrologiczny prowadzono w zlewni Rybnego Potoku z zastosowaniem pływakowego czujnika poziomu wody z rejestratorem Thalimedes firmy OTT, na posterunku hydrologicznym mieszczącym się w ujściowym odcinku potoku, poniżej Rybnej Polany (684 m n.p.m.). Ponadto monitoring prowadzono w dwóch przekrojach wodowskazowych umiejscowionych na Żarnowskim Potoku (powyżej ujścia; 775 m n.p.m.) oraz na potoku Szumiąca Woda (powyżej leśniczówki Stonów; 810 m n.p.m.).

Bezpośrednio po przejściu fali wezbraniowej podczas prowadzenia badań terenowych wybrano miejsca lokalizacji przekrojów poprzecznych doliny w celu obliczenia przepływu maksymalnego. Przepływ maksymalny obliczono wg wzoru: 
gdzie:

$$
Q_{\max }=P \cdot v
$$

$P$ - pole powierzchni przekroju poprzecznego koryta $\left[\mathrm{m}^{2}\right]$

$v$ - średnia prędkość przepływu $\left[\mathrm{m} \cdot \mathrm{s}^{-1}\right]$

Średnią prędkość przepływu wody obliczono, korzystając z wzoru Manninga (Kubrak, Nachlik 2003). Obliczone przepływy porównano z przepływami charakterystycznymi, obliczonymi zgodnie z zaleceniami IMGW za pomocą Formuły Opadowej (Biernat i in., 1991).

\section{WYNIKI}

\section{Uwarunkowania meteorologiczne wezbrania}

Na początku drugiej dekady maja 2014 r. nad Europą rozpoczął się intensywnie rozbudowywać niż nazwany „Yuette”. W dniach 13-14 maja ośrodek niżowy przemieścił się znad Półwyspu Bałkańskiego ku północy, nad południowo-zachodnią Rumunię. Natomiast z północnego-zachodu zaczęły napływać nad Polskę chłodne masy powietrza polarno-morskiego znad Atlantyku. W wyniku napływu z południowego-wschodu wilgotnych mas powietrza wystąpiły w zachodniej części Karpat intensywne opady deszczu. W rejonie Babiej Góry odnotowano wówczas opady wynoszące od 12,9 mm (Polana Rybna) do $37 \mathrm{~mm}$ (Zawoja) na dobę (Ryc. 3). Dwudniowe opady wynoszące od 30,9 mm w Jabłonce do $62 \mathrm{~mm}$ w Zawoi spowodowały zmniejszenie retencji i znaczne uwilgocenie zlewni.

Kolejnego dnia napływający znad Węgier i Rumunii ośrodek niżowy zaczął coraz silniej oddziaływać na warunki atmosferyczne występujące w Polsce. Układ ten spowodował napływ nad zachodnią część Karpat chwiejnych mas powietrza znad Ukrainy i wystąpienie intensywnych opadów deszczu. Ich natężenie dochodziło w godzinach wieczornych do $9,1 \mathrm{~mm} /$ godzinę. Po północnej stronie masywu Babiej Góry w ciągu doby spadło wówczas od 114,4 mm opadu w Makowie Podhalańskim do 138,0 mm w Zawoi. Po północy intensywność opadów jeszcze wzrosła (do 9,6 mm/godzinę). Ich stopniowe zanikanie rozpoczęło się ok. godz. 6.00, jednak przelotne opady deszczu trwały przez cały dzień. Drugiego dnia sumy opadów wyniosły od 33,5 $\mathrm{mm}$ w Makowie Podhalańskim do 80,1 mm na Rybnej Polanie. W ciągu dwóch dni najintensywniejszych opadów na Rybnej Polanie odnotowano 204,6 mm opadu. W okresie czterech dni (13-16 maj) ciągłych opadów odnotowano u północnych podnóży Babiej Góry od 241,5 do 243,5 mm opadu. Z kolei po południowej stronie jej grani opady były znacznie niższe i wyniosły do $175 \mathrm{~mm}$ na Hali Śmietanowej, z czego $139,7 \mathrm{~mm}$ opadu spadło w dniach 15-16 maja (Ryc. 3).

Opady te były najwyższymi dobowymi odnotowanymi w historii prowadzenia badań meteorologicznych w Zawoi (od 1961 r.). Opad w dniu 15 maja stano- 


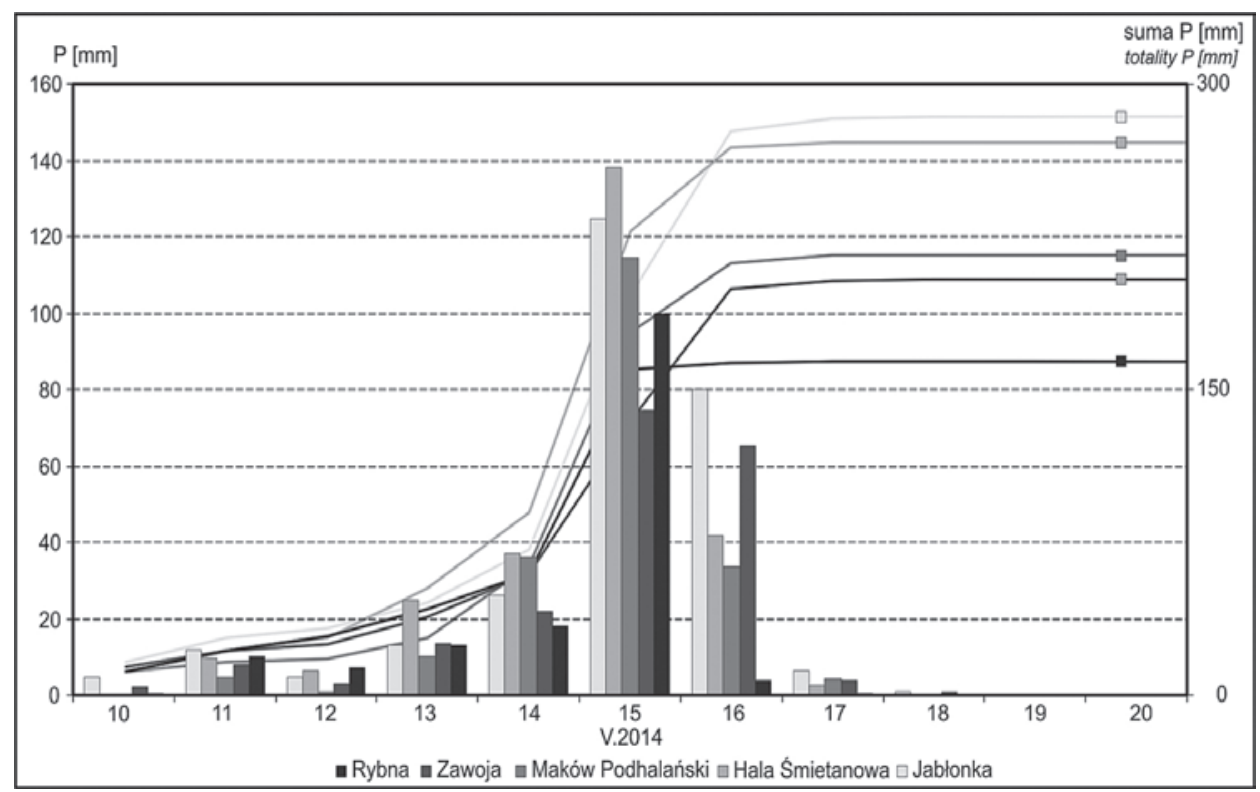

Ryc. 3. Opady atmosferyczne i krzywe sumaryczne w dniach 10-20 maja $2014 \mathrm{r}$.

Fig. 3. Percipitation and cumulative curver of percipitation of 10-20 $0^{\text {th }}$ May 2014

Źródło: opracowanie własne na podstawie danych IMGW-PIB i własnych pomiarów

Source: author's own study based on IMGW-PIB and own data

wił $232 \%$ średniego maksymalnego rocznego opadu deszczu i był o $15 \%$ wyższy od dotychczas najwyższego dobowego opadu, jaki wystąpił 18 lipca $1970 \mathrm{r}$. (120,1 mm) (Ryc. 4). Czterodniowy (16-19 lipca) opad był wówczas niemal identyczny jak w maju 2014 r. i wyniósł 243,8 mm. Zdecydowanie najwyższy dwudniowy opad wystąpił w Zawoi w dniach 31 sierpnia - 1 września 2010 r., gdy wyniósł on $216,9 \mathrm{~mm}$ i był wyższy od opadu z maja 2014 r. o $21 \%$ (Franczak 2013).

\section{Wezbranie w maju 2014 r.}

W pierwszej dekadzie maja 2014 r. poziom wody Rybnego Potoku kształtował się w strefie stanów niskich. Przepływ potoku wynosił około $0,10 \mathrm{~m}^{3} \cdot \mathrm{s}^{-1}$. Intensywny opad deszczu spowodował gwałtowną reakcję cieków, co przyczyniło się do uformowania się wysokiej fali wezbraniowej. W dniu 13 maja o godz. 19.00 w wyniku wystąpienia intensywnego opadu zaczęła się formować fala wezbraniowa. Systematyczny przybór wody trwał do godz. $7.00 \mathrm{w}$ dniu 15 maja, gdy osiągnięta została kulminacja pierwszej niewysokiej fali o wysokości $0,52 \mathrm{~m}$. Następnie w konsekwencji spadku intensywności opadów przepływ Rybnego Potoku nieznacznie zmalał, jednak o godz. 15.00 rozpoczął się gwałtowny przybór wód i tworzenie się głównej fali wezbraniowej. Najintensywniejszy wzrost pozio- 

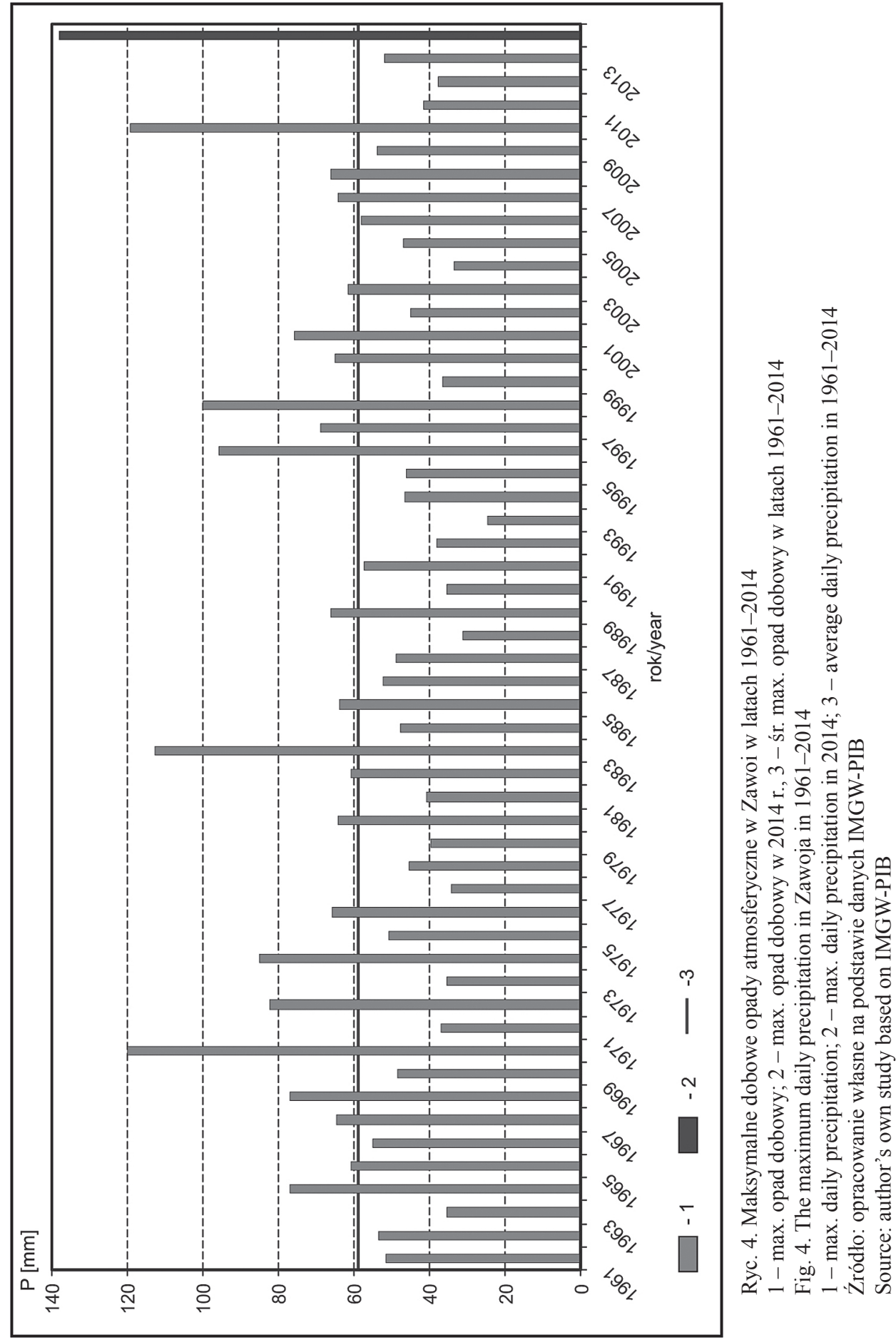


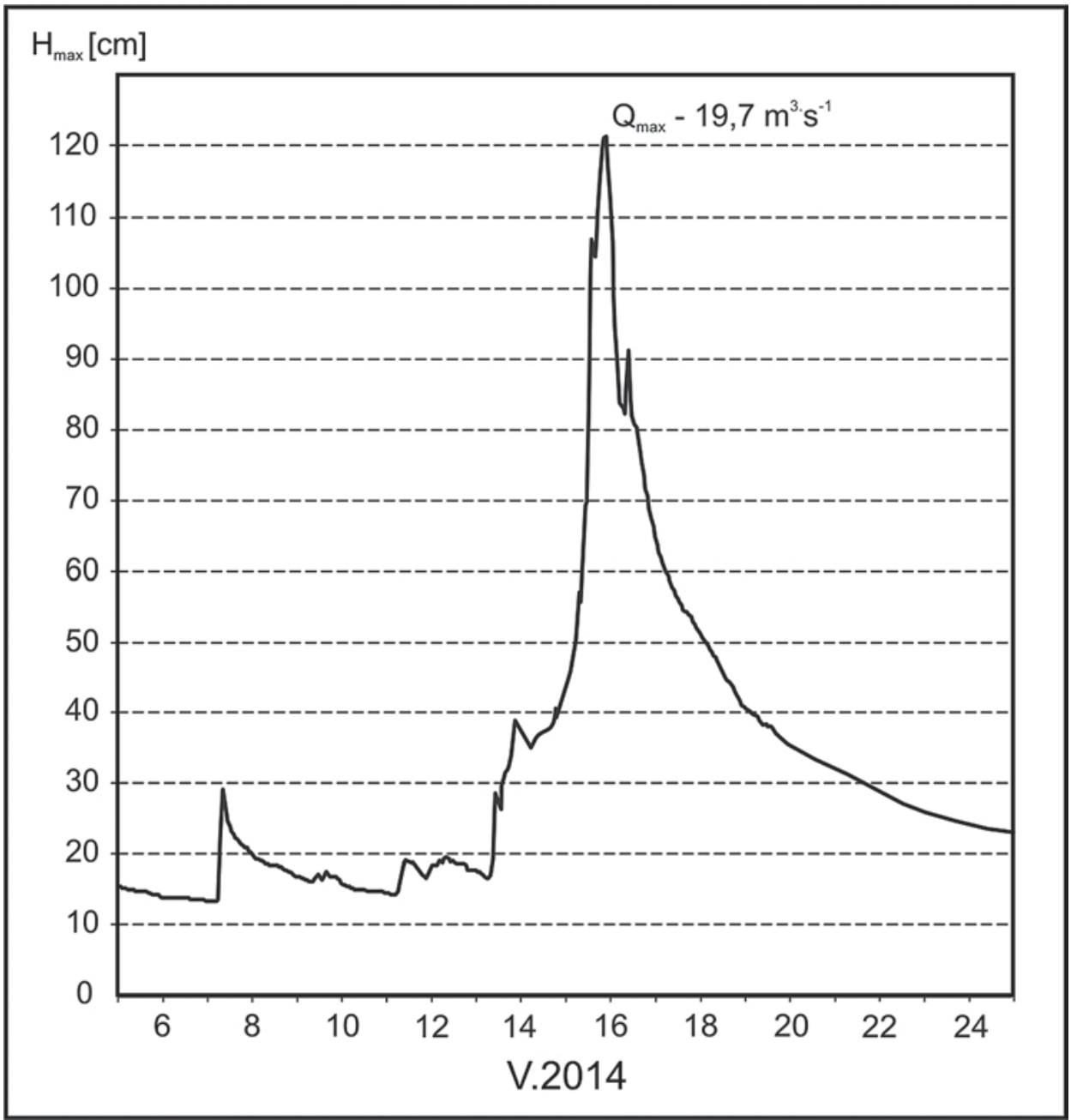

Ryc. 5. Hydrogram Rybnego Potoku w dniach 6-24 maja 2014 r.

Fig. 5. Hydrograph of Rybny Potok of 6-24 $4^{\text {th }}$ May 2014

Źródło: opracowanie własne

Source: author's own study

mu wody miał miejsce od godz. 21.00 do 00.00 , po czym jego tempo nieznacznie zmalało, jednak nadal systematycznie postępował wzrost wysokości fali wezbraniowej. Jej kulminacja została osiągnięta w dniu 16 maja o godz. 7.00, gdy stan wody Rybnego Potoku wyniósł 1,22 m, a przepływ określono na $19,7 \mathrm{~m}^{3} \cdot \mathrm{s}^{-1}$. Następnie rozpoczęło się szybkie opadanie wody w korycie, aż do osiągnięcia przez niego o godz. 15.00 poziomu $0,65 \mathrm{~m}$. W wyniku wzrostu intensywności opadu opadanie fali wezbraniowej uległo spowolnieniu, a o godz. 19.00 odnotowano 
nieznaczny wzrost przepływu, po czym dalej postępowała redukcja fali wezbraniowej. Tempo opadania było już jednak znacznie wolniejsze niż przez pierwsze siedem godzin po osiągnięciu kulminacji. Powrót Rybnego Potoku do wysokości przepływu sprzed wystąpienia wezbrania nastąpił w dniu 20 maja (Ryc. 5).

Maksymalny przepływ Rybnego Potoku w dolnym jego biegu (poniżej Rybnej Polany) (w przekroju I) wyniósł $19,7 \mathrm{~m}^{3} \cdot \mathrm{s}^{-1}$, a odpływ jednostkowy wyniósł $2,15 \mathrm{~m}^{3} \cdot \mathrm{s}^{-1} \cdot \mathrm{km}^{-2}$. W górnej części zlewni maksymalny przepływ Żarnowskiego Potoku wyniósł $5,90 \mathrm{~m}^{3} \cdot \mathrm{s}^{-1}$, a odpływ jednostkowy $2,14 \mathrm{~m}^{3} \cdot \mathrm{s}^{-1} \cdot \mathrm{km}^{-2}$. W trzecim przekroju znajdującym się na Szumiącej Wodzie tuż powyżej Polany Stonów maksymalny przepływ wyniósł $8,80 \mathrm{~m}^{3} \cdot \mathrm{s}^{-1}$, a odpływ jednostkowy $2,25 \mathrm{~m}^{3} \cdot \mathrm{s}^{-1} \cdot \mathrm{km}^{-2}$ (Tab. 1). Elewacja fali wezbraniowej w przekroju I wyniosła 1,04 m, natomiast w przekrojach II - 0,65 m, a III - 0,72 m. Fala wezbraniowa charakteryzowała się bardzo stromym nachyleniem fazy przyboru, podczas której tempo podnoszenia poziomu wody wynosiło nawet $0,17 \mathrm{~m} /$ godz. Faza wznoszenia fali wezbraniowej trwała 35 godz. (głównej kulminacji - 14 godz.), podczas gdy faza opadania trwała ok. 110 godz. (Ryc. 5).

Tabela 1. Maksymalny przepływy (Q) i odpływ jednostkowy (q) w zlewni górnej Skawicy

Table 1. The maximum flow (Q) and specific discharge (q) in the upper Skawica catchment

\begin{tabular}{|c|c|c|c|}
\hline $\begin{array}{c}\text { Zlewnia / } \\
\text { catchment }\end{array}$ & $\begin{array}{c}\text { Nr wodowskazu / } \\
\text { No. river gauge }\end{array}$ & $\mathrm{Q}\left[\mathrm{m}^{3} \mathrm{~s}^{-1}\right]$ & $\mathrm{q}\left[\mathrm{m}^{3} \cdot \mathrm{s}^{-1} \cdot \mathrm{km}^{-2}\right]$ \\
\hline \multicolumn{4}{|c|}{ Maj 2014/May 2014 } \\
\hline Rybny Potok & I & 19,70 & 2,15 \\
\hline Żarnowiecki Potok & II & 5,90 & 2,14 \\
\hline Szumiąca Woda & III & 8,80 & 2,25 \\
\hline Skawica & IV & 76,6 & 1,57 \\
\hline \multicolumn{4}{|c|}{ SWQ } \\
\hline Skawica & IV & 0,60 \\
\hline \multicolumn{4}{|c|}{$\mathbf{Q}_{\max }$} \\
\hline Skawica & IV & 120,1 \\
\hline
\end{tabular}

Zestawienie przepływu obliczonego podczas wezbrania z zlewni Rybnego Potoku z przepływami charakterystycznymi wykazuje, że w trakcie przemieszczania się kulminacji fali wezbraniowej niemalże osiągnięte zostały wartości o prawdopodobieństwie przewyższenia 5\% (tzw. woda dwudziestoletnia). Z kolei ze zlewni górnej Skawicy $\left(48,6 \mathrm{~km}^{2}\right)$ maksymalny przepływ osiągnął wartości niemalże równe obliczonemu przepływowi dla tzw. wody dziesięcioletniej (10\%). W zlewni górnej Skawicy było to czwarte z wezbrań o najwyższej kulminacji, od początku prowadzenia pomiarów w 1973 r. (Ryc. 6; Tab. 1, 2). Natomiast 


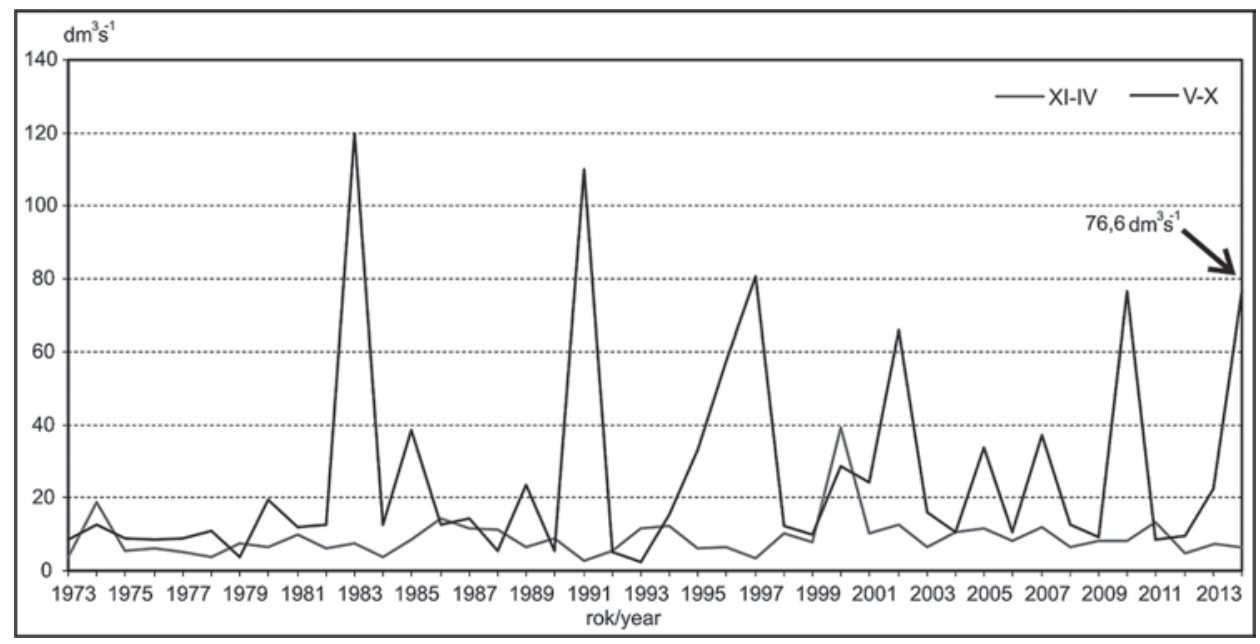

Ryc. 6. Maksymalne roczne przepływy (WWQ) Skawicy w Zawoi w latach 1973-2014

Fig. 6. The maximum annual water flow (WWQ) Skawica in Zawoja in 1973-2014

Źródło: opracowanie własne na podstawie danych IMGW-PIB

Source: author's own study based on IMGW-PIB data

Tabela 2. Przepływ (Q) i odpływ jednostkowy (q) o danym prawdopodobieństwie wystąpienia w zlewni Rybnego Potoku i Skawicy w Zawoi

Table 2. The flow $(\mathrm{Q})$ and specific discharge (q) of the probability of occurrence in the catchment Rybny Potok and Skawica in Zawoja

\begin{tabular}{|c|c|c|c|c|}
\hline \multirow{2}{*}{$\begin{array}{c}\text { Prawdopodobieństwo } \\
\text { probability }\end{array}$} & \multicolumn{2}{|c|}{ Rybny Potok } & \multicolumn{2}{c|}{ Skawica } \\
\cline { 2 - 5 } & $\mathrm{Q}\left[\mathrm{m}^{3} \cdot \mathrm{s}^{-1}\right]$ & $\mathrm{q}\left[\mathrm{m}^{3} \cdot \mathrm{s}^{-1} \cdot \mathrm{km}^{-2}\right]$ & $\mathrm{Q}\left[\mathrm{m}^{3} \cdot \mathrm{s}^{-1}\right]$ & $\mathrm{q}\left[\mathrm{m}^{3} \cdot \mathrm{s}^{-1} \cdot \mathrm{km}^{-2}\right]$ \\
\hline $50 \%$ & 3,3 & 0,36 & 21,9 & 0,45 \\
\hline $10 \%$ & 14,8 & 1,61 & 78,7 & 1,62 \\
\hline $5 \%$ & 20,5 & 2,23 & 104,9 & 2,16 \\
\hline $2 \%$ & 28,2 & 3,07 & 139,9 & 2,88 \\
\hline $1 \%$ & 33,8 & 3,68 & 168,6 & 3,47 \\
\hline $0,1 \%$ & 53,9 & 5,86 & 253,7 & 5,22 \\
\hline
\end{tabular}

znacznie przekroczony został średni z maksymalnych przepływów rocznych (SWQ), który na Skawicy w Zawoi wynosi $29,1 \mathrm{~m}^{3} \cdot \mathrm{s}^{-1}$. Zlewnia ta charakteryzuje się nieosiąganiem podczas intensywnych opadów deszczu przepływów o małym prawdopodobieństwie wystąpienia. Nawet podczas największego wezbrania w 1983 r. (Franczak 2013, 2014) $\left(Q_{\max }-120 \mathrm{~m}^{3} \cdot \mathrm{s}^{-1}\right.$; Ryc. 6) osiągnięty został przepływ o prawdopodobieństwie wystąpienia $2 \%$. Wyniki pomiarów z posterunku w Skawicy (pow. zlewni $139 \mathrm{~km}^{2}$ ) wykazują, iż było to największe wezbranie w XX w. (pomiary od 1928 r.) (Tab. 1, 2). 
W wyniku wystąpienia wezbrania znacznie zwiększyła się liczba wypływów w zlewni. Podczas najintensywniejszych opadów oraz przez kilka godzin po ich ustaniu wystąpił także spływ powierzchniowy, który uległ koncentracji w obrębie dróg leśnych i obniżeń terenu (Photo 1).

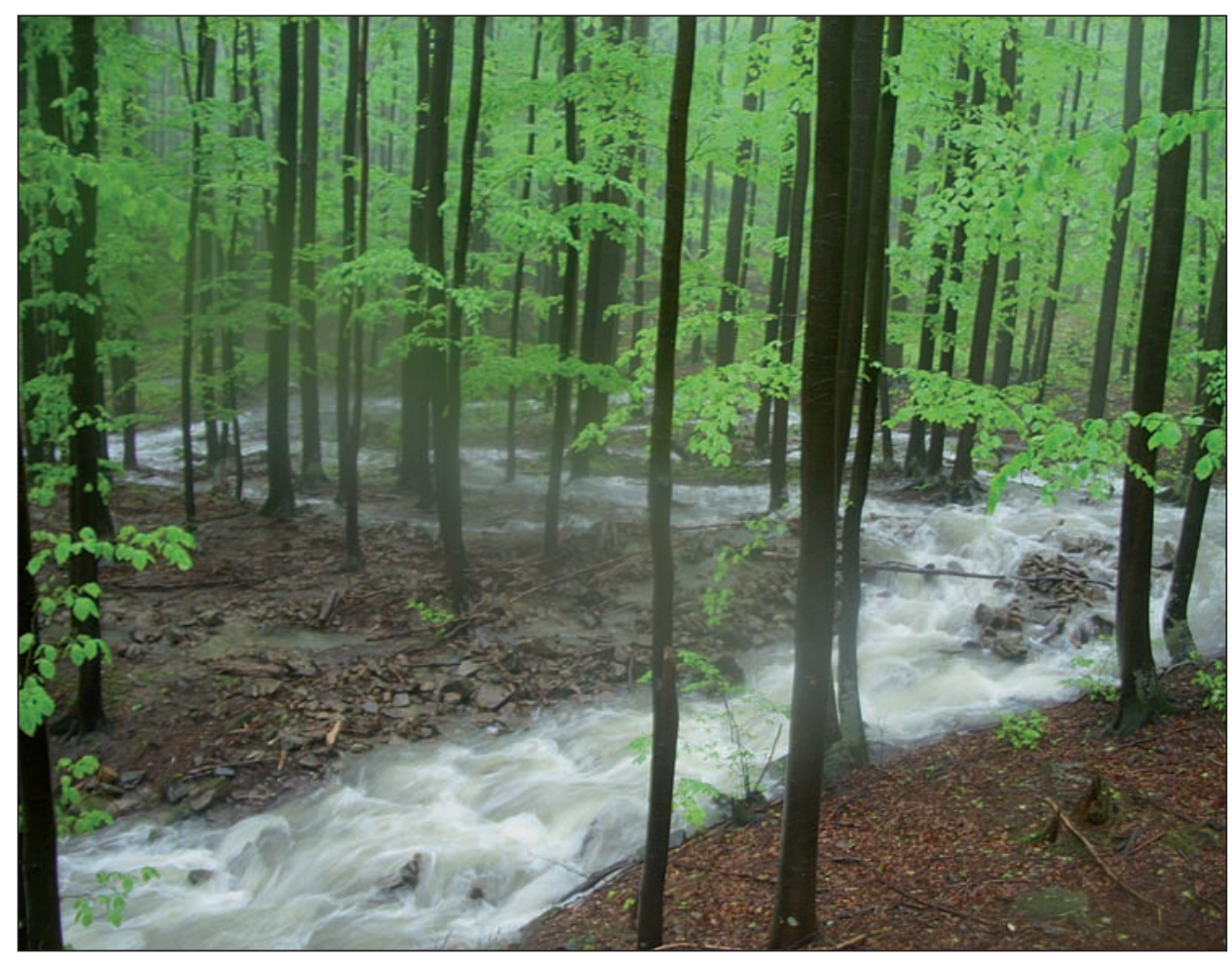

Fot. 1. Spływ powierzchniowy na stokach Masywu Babiej Góry w dniu 16 maja 2014 r. (fot. P. Franczak)

Photo 1. Surface runoff on the slopes of Babia Mountain Massif of 16 May 2014 (photo by P. Franczak)

\section{PRZEKSZTAŁCENIA GEOMORFOLOGICZNE KTÓRE NASTĄPIŁY W WYNIKU WEZBRANIA}

Wezbranie wywołane gwałtownymi opadami deszczu, które wystąpiły w nocy z 15 na 16 maja 2014 r. spowodowało rozległe przeobrażenia w zlewni Rybnego Potoku (Ryc. 7). Pomimo wielkiego przeobrażenia koryta, nie nastąpiły znaczące zmiany strukturalne, a jedynie doszło do zmiany liczby i rozmiarów form. W górnej części zlewni nastąpił wzrost rozmiarów form erozyjnych, natomiast w dolnym odcinku doszło do powstania wielu nowych form akumulacyjnych, którym towarzyszyły formy erozyjne. Na odcinkach płytko wciętego koryta 


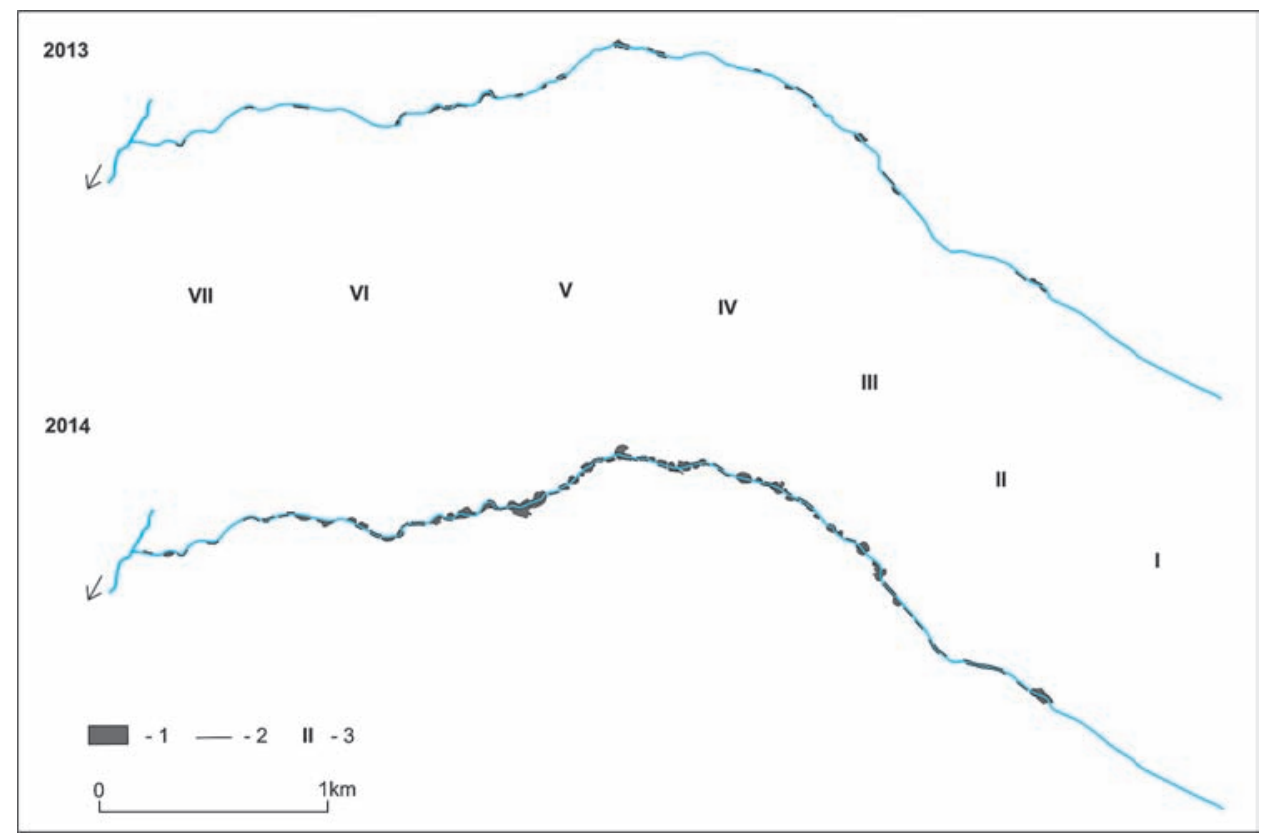

Ryc. 7. Przekształcenia geomorfologiczne powstałe w 2014 r. w wyniku wezbrania w zlewni Rybnego Potoku 1 - podcięcia erozyjne; 2 - łachy

Fig. 7. Geomorphological transformations caused by floods in the Rybny Potok catchment in 20141 - undercut erosion; 2 - cut bank

Źródło: opracowanie własne

Source: author's own study

wzrostowi rozmiarów form korytowych towarzyszyło powstanie rozległych form w obrębie terasy zalewowej.

Największe przeobrażenia koryta wystąpiły w dolnym odcinku biegu potoku (5), gdzie w największym rozszerzeniu dna doliny powstał szereg form akumulacyjnych (Ryc. 8, Fot. 2). Wzrost liczby i powierzchni form akumulacyjnych lecz na znacznie mniejszą skalę odnotowano również na całej pozostałej długości doliny. W górnym odcinku biegu koryta (powyżej Stonowa), powstała największa liczba podcięć brzegowych, których długość wzrosła 2-, 3-krotnie (Ryc. 8). Największe rozmiary osiągały one w odcinku 2, gdzie ich średnian długość wynosiła $80 \mathrm{~m}$. W rezultacie powstania w wąskim odcinku doliny licznych podcięć erozyjnych o wysokości dochodzącej do $7 \mathrm{~m}$, nastąpiło osunięcie na tym odcinku do koryta licznych drzew (Ryc. 9), które utworzyły rozlegle zwałowiska. W odcinkach koryta położonych poniżej, średnia długość podcięć była już zdecydowanie krótsza i wynosiła od 12 do 20 m. Mierzyły one od kilku do kilkunastu metrów 


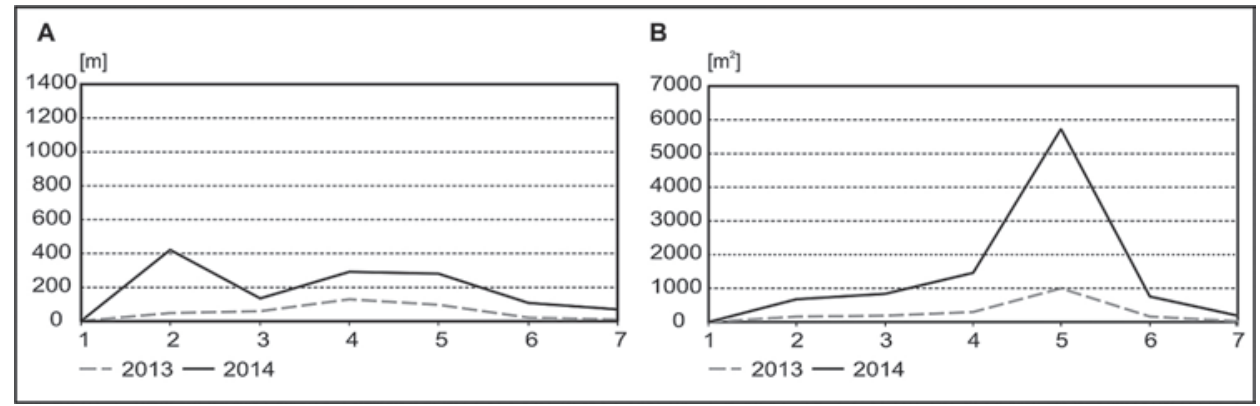

Ryc. 8. Zmiany wielkości form erozyjnych (A) i akumulacyjnych (B) w korycie Rybnego Potoku w latach 2013-2014

Fig. 8. Development of volumes forms of erosion (A) and accumulation (B) in the trough Rybny Potok in 2013-2014

Źródło: opracowanie własne

Source: author's own study

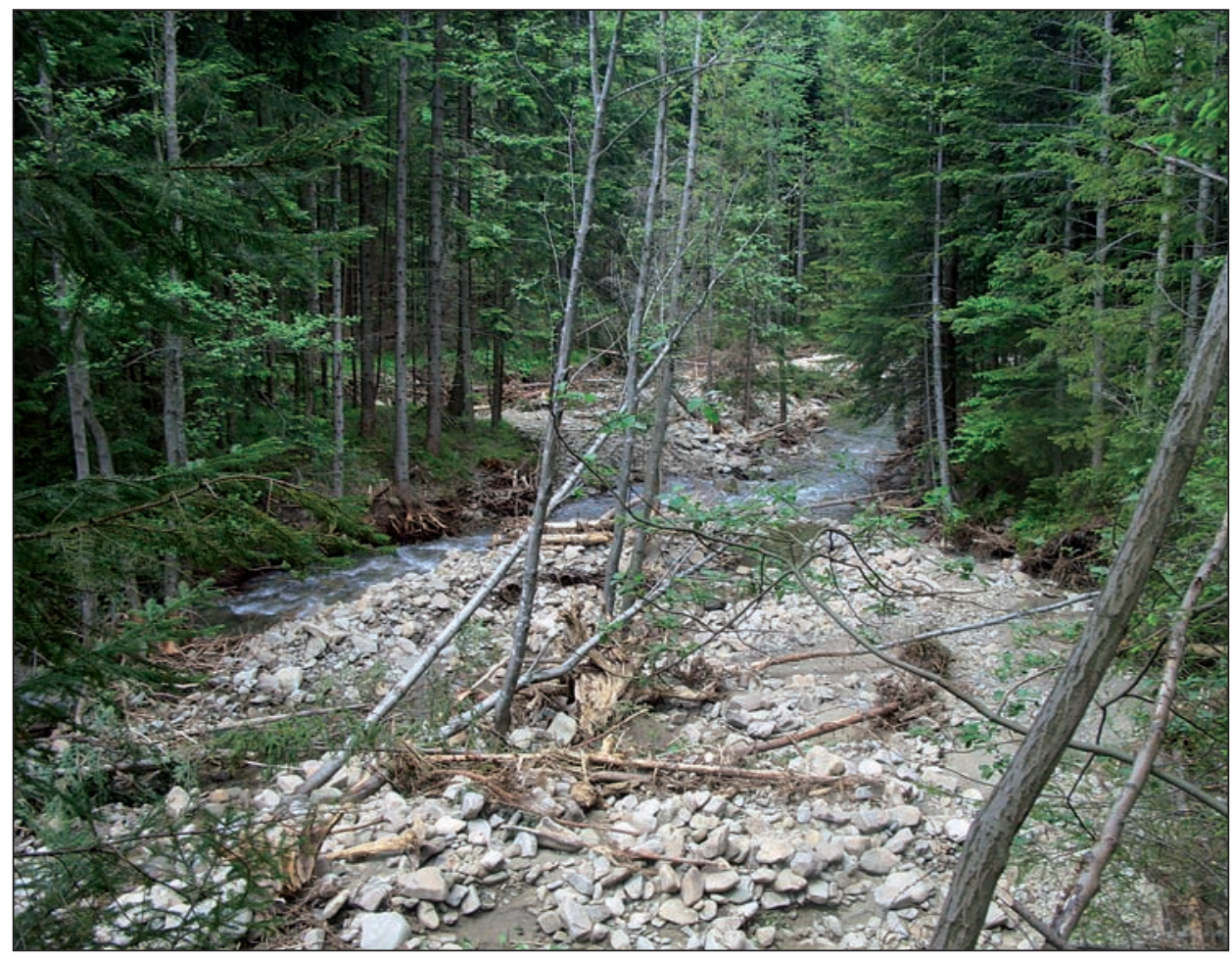

Fot. 2. Formy akumulacyjne powstałe w wyniku wezbrania w obrębie dna doliny Rybnego Potoku (fot. P. Franczak)

Photo 2. Forms accumulation caused by floods within the valley floor Rybny Potok (photo. P. Franczak) 


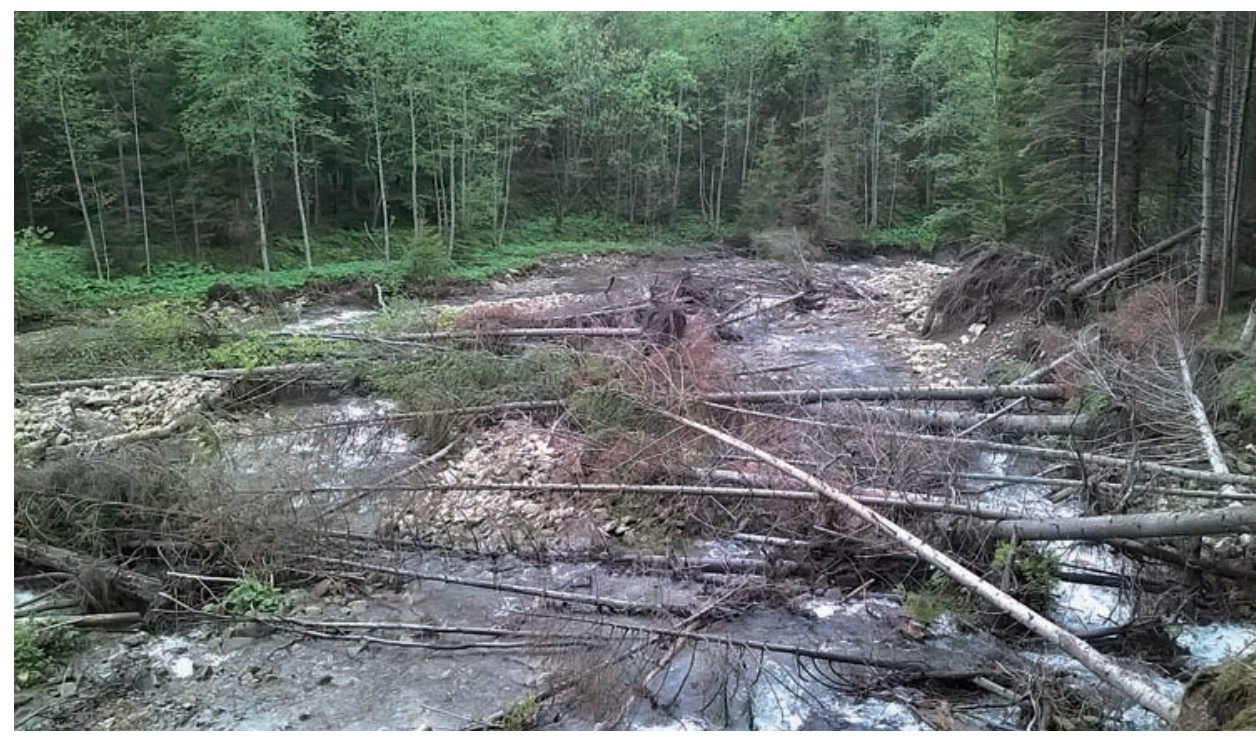

Fot. 3. Gruby rumosz drzewny w korycie Rybnego Potoku (fot. P. Franczak) Photo 3. Large woody debris in the trough Rybny Potok (photo. P. Franczak)

długości, a ich wysokości osiągały 1-1,5 m. Jedynie w obrębie zakoli potoków, u podnóży wysokich teras nadzalewowych, osiągnęły one do $6 \mathrm{~m}$ wysokości. W górnej części zlewni doszło także do znacznego wcięcia koryt potoków na głębokość ok. 0,4 m, a na obszarach o najintensywniejszym oddziaływaniu erozji wgłębnej koryta wcięły się o $1,1 \mathrm{~m}$ (Fot. 3). W dolnym biegu potoku nastąpiło obniżenie dna koryta o ok. $0,2 \mathrm{~m}$.

Największe przeobrażenia dna doliny Rybnego Potoku wystąpiły we wspomnianym już wcześniej odcinku 5, gdzie powstał szereg rozległych form akumulacyjnych. Do zaszłych tam znacznych zmian przyczyniło się porośnięcie bezpośredniego sąsiedztwa koryta oraz terasy zalewowej przez płaty olszynki górskiej i świerczyny, na których nastąpiła akumulacja niesionego materiału, podczas przemieszczania się fali wezbraniowej. Powstały tam rozległe zwałowiska materii organicznej o wysokości dochodzącej do $3 \mathrm{~m}$, za którymi tworzyły się żwirowiska. Poniżej powstawały rozcięcia erozyjne o głębokości dochodzącej do 1,5 m. Na największym ze zwałowisk zalegało kilkadziesiąt kłód grubego rumoszu drzewnego. Na tym odcinku biegu potoku nastąpiło niemalże 6-krotne zwiększenie powierzchni zajmowanej przez łachy $\left(\right.$ do $\left.5750 \mathrm{~m}^{2}\right)$. Ich średnia powierzchnia wyniosła $358 \mathrm{~m}^{2}$, jednakże poprzez wykształcenie się części z nich obok siebie tworzyły one rozległy system łach. Największy z nich mierzył $2170 \mathrm{~m}^{2}$ powierzchni. Większość zdeponowanego na ich obszarze materiału mierzyła $0,1-0,3 \mathrm{~m}$ średnicy, natomiast największe przemieszczone bloki pia- 
skowcowe osiągały do $0,80 \mathrm{~m}$. Z kolei w obrębie zalesionej terasy zalewowej powstały liczne odsypy pozakorytowe o frakcji żwirowej i piaszczystej. Największy wzrost liczby łach nastąpił na odcinku 4, gdzie rozmiary powstałych form były znacznie mniejsze niż $\mathrm{w}$ odcinku 5 , a ich średnia powierzchnia wyniosła $48 \mathrm{~m}^{2}$. Pomimo powstania w dolnym odcinku biegu Rybnego Potoku licznych form akumulacyjnych wykształciło się tam też wiele form erozyjnych. Powstały liczne podcięcia brzegowe, ale także rozległe rozcięcia linijne wykształcone $\mathrm{w}$ aluwiach oraz w litym podłożu skalnym. Mierzyły one średnio do $50 \mathrm{~m}$ długości, a ich głębokość dochodziła do $1 \mathrm{~m}$. Wyjątek stanowi najokazalsza $\mathrm{z}$ form, powstała w obrębie terasy nadzalewowej na zakolu rzeki, która mierzy 8 m szerokości i 2,4 m głębokości.

Na całym odcinku badanego potoku wystąpiło wyraźne poszerzenie jego koryta. Jego szerokość w dolnym odcinku uległa poszerzeniu z 3-10 m miejscami aż do $25 \mathrm{~m}$. Z kolei w górnym odcinku, gdzie dolina jest wąska, a koryto głęboko wcięte, jego szerokość wzrosła z 3-5 m do 5-7 m.

\section{PODSUMOWANIE}

Intensywne opady deszczu, które wystąpiły w maju 2014 r. w zlewni górnej Skawicy wywołały jedno z największych wezbrań odnotowanych na badanym obszarze od początku prowadzenia pomiarów w 1973 r. Dwudniowe opady, których suma przekroczyła $200 \mathrm{~mm}$ przyczyniły się do szybkiego wezbrania cieków i uformowania w ciągu kilkunastu godzin stromej fali wezbraniowej. Uruchomieniu uległ również spływ powierzchniowy, a odpływ jednostkowy wyniósł ponad $2 \mathrm{~m}^{3} \cdot \mathrm{s}^{-1} \cdot \mathrm{km}^{-2}$. W wyniku przemieszczenia się fali wezbraniowej do największej transformacji koryta i dna doliny doszło w zlewni Rybnego Potoku. W górnej części zlewni zaszła intensywna erozja, natomiast w jej dolnej i środkowej części powstały rozległe formy akumulacyjne. W znacznej mierze do ich powstania przyczyniło się porośnięcie terasy zalewowej przez zwarty drzewostan, w wyniku czego podczas transportu przez falę rumoszu drzewnego dochodziło do jego zatrzymywania się i uformowania licznych zwałowisk, powyżej których powstały formy akumulacyjne.

Pomimo wystąpienia w zlewni jednych z największych w historii opadów, a także powstania licznych przeobrażeń rzeźby po raz kolejny potwierdzone zostało, iż w zlewni górnej Skawicy nie występują wezbrania o niskim poziomie prawdopodobieństwa. Nawet podczas największego z nich (w 1983 r.) nie został przekroczony przepływ o prawdopodobieństwie wystąpienia $2 \%$ (tzw. woda pięćdziesięcioletnia). Wskazuje to, że pomimo posiadania cech rzeźby sprzyjających kształtowaniu gwałtownych wezbrań, ich kulminacje są znacząco niższe. Przy- 
czyniać się do tego może duże zalesienie zlewni oraz występowanie głębokich osuwisk zwiększających retencję zlewni.

Autor pragnie serdecznie podziękować obu Recenzentom za cenne uwagi, które niewątpliwie przyczyniły się do podniesienia jakości artykułu.

Badania przeprowadzono w ramach projektu finansowanego ze środków Wydziału Biologii i Nauk o Ziemi Uniwersytetu Jagiellońskiego na podstawie decyzji numer K/DSC/002358 oraz NFOŚiGW w ramach umowy 298/2011/Wn-50/ OP-MN/D. Badania terenowe przeprowadzono na podstawie zezwolenia Dyrektora Babiogórskiego Parku Narodowego nr 69/2014.

\section{LITERATURA}

Bajgier-Kowalska M., Ziętara T., 2008. Wpływ gwaltownych opadów na modelowanie rzeźby w Dolinie Kościeliskiej w Tatrach Zachodnich, Landform Analysis, 8, 5-8.

Bryndal T., 2008. Parametry zlewni, w których wystapity lokalne powodzie, Annales UMCS, Sectio B, Geographia, Geologia, Mineralogia et Petrographia, 63, 177-200.

Bryndal T., 2009. Przeptywy maksymalne odnotowane podczas gwattownych wezbrań, spowodowanych krótkotrwatymi ulewnymi opadami deszczu w matych zlewniach karpackich, [w:] (red.) R. Bogdanowicz, J. Fac-Beneda, Zasoby i ochrona wód. Obieg wody i materii w zlewniach rzecznych, Fund. Roz. UG, Gdańsk, 329-334.

Bryndal T., 2010. Parametry hydrologiczne wezbrań spowodowanych krótkotrwałymi intensywnymi opadami deszczu w Polsce, Annales UMCS, Sectio B, Geographia, Geologia, Mineralogia et Petrographia, 65, 43-71.

Bryndal T., 2011. Identyfikacja matych zlewni podatnych na formowanie gwaltownych wezbrań (na przykładzie Pogórza Dynowskiego, Strzyżowskiego i Przemyskiego), Przegląd Geograficzny, 83, 1, 27-49.

Bryndal T. 2014. Znaczenie map zagrożenia oraz ryzyka powodziowego w ograniczeniu skutków powodzi blyskawicznych w miastach, [w:] (red.) T. Ciupa, R. Suligowski, Woda w mieście, IG UJK w Kielcach, Kielce, 29-37.

Bryndal T., Cabaj W., Ciupa T. 2008. Gwaltowne wezbrania małych cieków w Niecce Nidziańskiej, Przegląd Geograficzny, 80 (1), 127-146.

Bucała A., Budek A., 2011. Zmiany morfologii koryt wskutek opadów ulewnych na przykładzie potoku Suszanka, Beskid Średni, Czasopismo Geograficzne, 82, 4, 321-332.

Cabaj W., Ciupa T., Bryndal T., 2002. Rola czynników naturalnych $i$ antropogenicznych $w$ ksztattowaniu lokalnych powodzi w potudniowej części Wyżyny Małopolskiej, [w:] (red.) T. Ciupa, E. Kupczyk, R. Suligowski, Obieg wody w zmieniającym się środowisku. Prace Instytutu Geografii AŚ, Kielce, 7, 353-360.

Ciepielowski A., 1970. Maksymalne wielkości spływów jednostkowych z deszczów nawalnych, Przegląd Geograficzny, 15, 2, 179-193.

Dębski K., 1969. O potencjalnym najwyższym odpływie z krótkotrwałych deszczów nawalnych, Rozpr. Hydrotechn., 23, 51-63.

Długosz M., Gębica P., 2008. Geomorfologiczne skutki oraz rola lokalnych ulew i powodzi w ksztattowaniu rzeźby progu Pogórza Karpackiego (na przykładzie ulewy z czerwca 2006 r. w rejonie Sędziszowa Młp.), Landform Analysis, 8, 13-20.

Franczak P., 2013. Zagrożenie powodziowe w zlewni górnej Skawy, praca magisterska, Zakład Hydrologii IGiGP UJ, mps. 
Franczak P., 2014. Rola wielkich wezbrań powodziowych w kształtowaniu życia ludności w zlewni górnej Skawy od XV wieku, [w:] (red.) P. Krąż, Współczesne problemy i kierunki badawcze w geografii, 2, IGiGP UJ, Krakow, 117-129.

Gaume E., Bain V., Bernardara P., Newinger O., Barbuc M., Bateman A., Blaškovičová L., Blöschl G., Borga M., Dumitrescu A., Daliakopoulos I., Garcia J., Irimescu A., Kohnova S., Koutroulis A., Marchi L., Matreata S., Medina V., Preciso E., Sempere-Torres D., Stancalie G., Szolgay J., Tsanis I., Velasco D., Viglione A., 2009. A compilation of data on European flash floods, Journal of Hydrology, 367, 1-2, 70-78.

Gorczyca E., 2004. Przekształcanie stoków fliszowych przez procesy masowe, podczas katastrofalnych opadów (dorzecze Łososiny). Wyd. UJ, Kraków, 1-101.

Gorczyca E., Krzemień K., 2008. Morfologiczne skutki ekstremalnego zdarzenia opadowego w Tatrach Reglowych w czerwcu 2007 r., Landform Analysis, 8, 21-24.

Gorczyca E., Wrońska-Wałach D., 2008. Transformacja matych zlewni górskich podczas opadowych zdarzeń ekstremalnych (Bieszczady), Landform Analysis, 8, 25-28.

Izmaiłow B., Kamykowska M., Krzemień K., 2008. Geomorfologiczna rola katastrofalnych wezbrań w transformacji górskiego systemu korytowego na przykładzie Wilszni (Beskid Nicki), [w:] (red.) B. Izmaiłow, Przyroda - Człowiek - Bóg, Kraków, 69-81.

Krzaklewski P., 2008. Rola zdarzeń ekstremalnych $w$ ksztattowaniu meandrowych koryt górskich na przyktadzie Czarnej Orawy w okresie 2007-2008, Landform Analysis, 8, 45-48.

Kubrak J., Nachlik E. (red.), 2003. Hydrauliczne podstawy obliczania przepustowości koryt rzecznych, Wyd. SGGW, Warszawa.

Lach J., Lewik P., 2002. Powódź w lipcu 2001 na Sądecczyźnie i jej skutki, [w:] (red.) Z. Górka A. Jelonek, Geomorfologiczne uwarunkowania rozwoju Małopolski, Instytut Geografii UJ, Kraków, 199-204.

Lenart W., 1993. Opad atmosferyczny, [w:] (red.) U. Soczyńska, Podstawy hydrologii dynamicznej, Wyd. UW, Warszawa, 101-116.

Łach J., 2003. Zmiany w morfologii den dolinnych Nysy Kłodzkiej i Biatej Lądeckiej powstate w wyniku powodzi w lipcu 1997 roku, praca doktorska, archiwum Instytutu Geografii i Rozwoju Regionalnego Uniwersytetu Wrocławskiego, mps.

Łajczak A., 2008. Wody Babiej Góry, [w:] (red.) B.W. Wołoszyn, A. Jaworski, J. Szwagrzyk, Babiogórski Park Narodowy. Monografia przyrodnicza, Zawoja-Kraków, 153-177.

Parczewski W., 1960. Warunki występowania nagłych wezbrań na małych ciekach, Wiad. Służby Hydrolog. i Meteorolog., 8, 3, 1-159.

Pociask-Karteczka J., Żychowski J., 2014. Powodzie błyskawiczne (flash floods) - przyczyny i przebieg, [w:] (red.) T. Ciupa, R. Suligowski, Woda w mieście, IG UJK w Kielcach, Kielce, 213-226.

Starkel L., 2011. Złożoność czasowa i przestrzenna opadów ekstremalnych - ich efekty geomorfologiczne i drogi przeciwdziałania im, Landform Analysis, 15, 65-80.

Ziętara T., 2002. Rola gwaltownych ulew i powodzi w modelowaniu rzeźby terenu oraz niszczeniu infrastruktury osadniczej w górnej części dorzecza Wisty, [w:] (red.) Z. Górka, A. Jelonek, Geomorfologiczne uwarunkowania rozwoju Małopolski, Wyd. UJ, Kraków, 37-45.

Żurawek R., 1999. Zmiany erozyjne $w$ dolinach rzek Sudetów Kłodzkich wywołane powodziami w lipcu 1997 r. oraz w lipcu 1998 r., Problemy Zagospodarowania Ziem Górskich, 45, 45-61. 


\section{SUMMARY}

Mountain streams are subject to continuous modeling of river beds during floods. The greatest changes occur within them, however, during the catastrophic floods caused by sudden rainfall. The increase in the intensity of transformation occurs in forest areas, where the wooden logs carried by the swollen streams create a dumping ground, around which there is a greater accumulation of transported material and the formation of an increased mosaic of geomorphological forms.

The study was conducted in the Rybny Potok catchment area (Babia Góra National Park). The flooding occurred on 15-16 May 2014 due to the heavy rainfall, which on 15 May amounted to $138 \mathrm{~mm}$. Whereas $216.5 \mathrm{~mm}$ of rainfall fell in the catchment area in three days. This resulted in a sudden and full spate streams, contributing to a significant transformation in the bottoms of their geomorphological valleys. There were created many new forms, while the pre-existing increased their size. 